\title{
Afastamento para o Exterior
}

\section{Corsíndio Monteiro da Silva}

Assistente Jurídico do DASP

O afastamento do servidor público para o exterior pode dar-se em seis hipóteses: 1) a serviço da União; 2) em razão de bolsa de estudo ou desempenho de atividades com vistas a seu aperfeiçoamento funcional; 3) para servir em organizaCões internacionais com as quais o Brasil coopere, tais como a ONU, a FAO, a UNESCO, o Instituto Interamericano de Ciências Agrícolas, a Organização Mundial de Saúde; 4) para participar de competição desportiva internacional de amadores; 5) para fins religiosos ou de interesse cultural e, finalmente, 6) a do ocupante de cargo de magistério superior, para estudo ou missão oficial no exterior.

A primeira hipótese tem, agora, novo disciplinamento: a Lei n. 5.809 , de 10 de outubro de $1972^{1}$, regulamentada pelo Decreto n. 71.733 , de 18 de janeiro de $1973^{2}$.

Vamos examinar em forma de diálogo o ordenamento juridico positivo existente sobre o assunto.

Referida Lei $n .^{\circ} 5.809$, de 1972 , dispõe especificamente sobre a retribuição e direito do pessoal civil e militar em serviço da União no exterior do País. É a chamada Lei de Retribuição no Exterior.

- Donde se conclui que essa lei regula a retribuição e o direito do pessoal civil e militar em serviço no exterior e não propriamente o afastamento de servidores para o exterior!

1. Díário Oficlal de 13 de outubro de 1972. Republicada no Diárlo Oficlal de 19 de outubro de 1972, por haver saído com incorreçóes.

2. Diário Oficial de 19 de Janeiro de 1973. Partes retificadas no Diário Oficlal de 24 de janeiro de 1973, p. 827. 
- Como se sabe, é prerrogativa constitucional do Presidente da República, exercer a direção superior da administração federal. Se o funcionário público precisa da autorização do Presidente da República para afastar-se de sua repartição para ter exercício em outra, por qualquer motivo (Parágrafo único do artigo 34 da Lei n. 1711 , de 28 de outubro de 1952), não podendo ausentar-se do País, para estudo ou missão oficial com ou sem

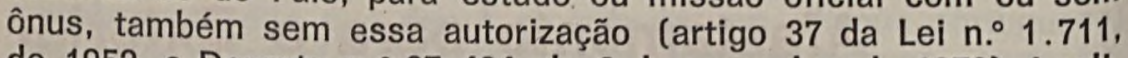
de 1952, e Decreto $n .^{\circ} 67.494$, de 6 de novembro de 1970), implicitamente se admite a possibilidade do afastamento e a competência para autorizá-lo. E esse Decreto n. ${ }^{\circ} 67.494$, de 1970, dispõe, expressamente, sobre afastamento para o exterior de servidor ou empregado público da administração direta e indireta. De modo que a Lei $n .^{\circ} 5.809$, de 1972 , parte do pressuposto da viabilidade legal desse afastamento que é disciplinado por legislação específica. Por exemplo. o Decreto-lei $n$. $^{\circ} 1.565$, de 5 de setembro de 1939 , ainda em vigor, dispõe sobre a nomeação de Delegados do Brasil a Congressos, Conferências e reuniões internacionais no país e no estrangeiro, nomeação essa que será feita por decreto do Presidente da República, referendado pelo Ministro das Relações Exteriores; o Decreto-lei n. 9.538 , de $1 .^{\circ}$ de agosto de 1946, também em vigor, dispõe sobre o afastamento de servido. res brasileiros para trabalho junto a Organizações Internacionais com as quais coopere o Brasil.

Já o afastamento do ocupante de cargo do magistério superior está autorizado pelo artigo 35 da Lei n. $4.881-A$, de 6 de dezembro de 1965 (Estatuto do Magistério Superior), e se processa nos termos da Lei $n .^{\circ} 5.096$, de 31 de agosto de 1966 . O artigo 24 do Decreto $n .^{\circ} 59.676$, de 6 de dezembro de 1966, regulamentou a matéria.

Note-se que a Lei n. 5.809 , de 1972 , diz, em seu artigo 1. , que "regula a retribuição no exterior e dispõe sobre outros direitos dos funcionários públicos e dos militares, em serviço da União, no exterior", e, logo a seguir, define o que seja servidor público para os efeitos dessa lei...

- Não seria talvez mais técnico dizer que dispõe sobre outros direitos dos servidores públicos?

- De fato. Mas, para os efeitos da Lei n. ${ }^{\circ} 5.809$, de 1972 , servidor público é o funcionário ou empregado público e o militar.

- Quer dizer que foi tomada a expressão "servidor público" em sentido lato ou genérico, abrangendo o funcionário, o empregado e o militar? 
- Realmente. E as disposições dessa lei são abrangentes, praticamente, de toda a gama de servidores públicos, não só da Administração Federal Direta como da Indireta e das Fundações sob supervisão ministerial, como do Poder Legislativo, do Poder Judiciário e do Tribunal de Contas da União, inclusive às pessoas sem vínculo com o serviço público, designados pelo Presidente da República, excluídos somente os servidores de Empresa Pública e de Sociedade de Economia Mista quando em serviço específico do órgão no exterior do País.

- Se as disposições dessa lei se aplicam às pessoas sem vínculo com o serviço público, designados que sejam pelo Presidente da República, não seria caso de considerá-las também incluídas no conceito de servidores públicos?

- Com efeito. Enquanto estiverem essas pessoas a servico da União no exterior devem elas ser consideradas como ser. vidor público, dentro da amplitude do conceito, não só porque fazem jus aos benefícios dessa legislação específica como por motivos de ordem disciplinar ou mesmo penal.

- A quais servidores especificamente se aplicam as disBosições dessa Lei de Retribuição no Exterior?

- Aplica-se aos servidores da Administração Federal Direta, estatutários ou regidos pela legislação trabalhista, da Administração Federal Indireta e das Fundações sob supervisão ministerial, isto é, das chamadas Fundações instituídas pelo Poder Público; aos servidores do Poder Legislativo, do Poder Judiciário e do Tribunal de Contas da União e, no que couber, aos servidores do Distrito Federal, dos Estados e dos Municípios, bem como às pessoas sem vínculo com o serviço público, designadas pelo Presidente da República.

\section{- E os servidores do Tribunal de Contas do Distrito Fede. dos Estados?}

- A lei não diz que a esses servidores também se aplicam Suas disposições, mas é de concluir que devem ser elas aplicadas, não só porque dispõe que se aplicam aos servidores do Distrito Federal e dos Estados como em face do disposto no artigo 13 , item V, da Constituição Federal, que manda que os Estados adotem as normas relativas aos funcionários públicos federais. A dúvida que poderia surgir seria nos Estados, pois que o assunto dependeria de lei estadual, mas a norma poderia ser adotada na elaboração dessa lei. É de crer, ainda, que essa dúvida pode- 
ria ficar sem sentido se, para missão no exterior, fosse aqueles servidores designados pelo Presidente da República.

- $O$ pessoal abrangido pelas disposições dessa Lei de Retribuição no Exterior, quando em serviço, continuaria a perceber as vantagens referentes ao cargo ou emprego que ocupa?

- Não. É vedado a esse pessoal, inclusive ao militar, o pagamento, pelos cofres públicos, por motivo de serviço da União no exterior, de qualquer forma de retribuição, remuneração e outras vantagens ou indenizações não previstas nesse diploma legal.

- Quais as missões ou atividades que ensejarão a retribuição e direitos previstos na Lei de Retribuição no Exterior?

- O pessoal em serviço no exterior - assim considerado aquele que se encontra em missão fora do País por haver sido nomeado ou designado para o desempenho ou exercício de cargo, função ou atividade no exterior - pode ser incluído em uma das seguintes missões ou atividades, distribuídas segundo o tipo ou sua natureza. Quanto ao tipo : missão permanente, missão transitória e missão eventual. Quanto à natureza : diplomática, militar e administrativa.

\section{- Que se entende por missão de caráter permanente?}

- Considera-se permanente a missão na qual o servidor deve permanecer em serviço, no exterior, por prazo igual ou su. perior a dois anos, em missão diplomática, em repartição consular ou em outra organização, militar ou civil, no desempenho ou exercicio de cargo, função ou atividade, considerados permanentes através de decreto. De modo que serão discriminados em decreto específico os órgãos cujos cargos, funções ou atividades - desempenhados ou exercidos nas condições estabelecidas na Lei de Retribuição no Exterior - se considerarem permanentes. ${ }^{3}$ Cumpre notar que o servidor do Ministério das Relações Exteriores só será considerado em missão permanente no exterior quan. do for lotado em unidade administrativa do mesmo Ministério no exterior.

Em síntese, a designação para o exercício de missão permanente determina: a) a mudança de sede, do País para o exte-

3. O Decreto n. ${ }^{\circ} 72.021$, de 28 de março de 1973 , discrimina os órgăos cujos cargos, funçōes ou atividades, desempenhados nas condições da Lei de Retribuiçăo no Exterior, se consideram permanentes. Diário Oficial de 29 de março de 1973. 
rior, ou de uma para outra sede no exterior; e b) para o servidor do Ministério das Relações Exteriores, também a alteração de sua lotação.

\section{- E missão transitória?}

- Transitória é a missão na qual o servidor tem de permanecer em serviço no exterior, com mudança de sede ou sem mudança de sede. nas seguintes hipóteses: 1) designado para o exercício, em caráter provisório, de missão considerada permanente; 2) como professor, assessor, instrutor ou monitor, por prazo inferior a dois anos, em estabelecimento de ensino ou técnico. científico, e, por qualquer tempo, se se tratar de estagiário ou aluno nesses estabelecimentos ou organizações industriais; 3 ) como participante de viagem ou cruzeiro de instrução; 4) em missão de representação, de observação ou em organismo ou reuniões internacionais; 5) como comandante ou integrante de tripulação, contingente ou força, em missão operativa ou de adestramento, em país estrangeiro, e 6) em razão de encargos especiais.

de para efeito de aplicação dessa lei?

- Falou-se em mudança de sede... Qual o conceito de se-

- Considera-se sede no exterior : 1) no caso dos servidores do Ministério das Relações Exteriores sejam eles diplomatas ou não, e dos Adidos Militares e seus Adjuntos ou Auxiliares, a cidade onde está localizada a sede da missão diplomática ou da repartição consular de sua lotação; 2) nas comissões exercidas a bordo, o navio; e 3) nos demais casos, a cidade, o município ou a unidade correspondente da divisão territoral político-administra. tiva do País em que se situa a organização para a qual haja sido nomeado ou designado o servidor.

- Muito bem. De modo que há, então, missões transitórias com mudança de sede, e outras, sem essa mudança?

- Realmente.

dança de Qual a duração provável da missão transitória, com mu.
sede

- Pode ser igual ou superior a seis meses; inferior a seis meses, e superior ou igual a três meses, e inferior a três meses.

- E as missões transitórias, sem mudança de sede?

- Têm duração variável, e, em princípio, inferior a um ano. 
- Além da missão permanente e da transitória, temos a missão eventual. Que se entende por missão eventual?

- É uma missão que não requer mudança de sede ou alteração de lotação, e por período que não exceda de noventa dias. Nesse tipo de missão, o servidor tem de permanecer no exterior em uma das seguintes situações, sejam estas em território nacional, sejam no exterior ou em navio: 1) quando designado para c exercício, em caráter provisório, de missão considerada permanente ou transitória; 2) quando membro de delegação de comitiva ou de representação oficial; 3) quando em missão de representação, de observação ou em organismo ou reuniões internacionais; 4) como comandante ou integrante de tripulação, contingentes ou força, em missão operativa ou de adestramento em país estrangeiro; 5) quando em serviço especial de natureza diplomática, administrativa ou militar, e 6) quando designado para encargos especiais.

- Vimos que, nos demais casos, considera-se sede no exterior a cidade, o município ou unidade correspondente da divisão territorial político-administrativa do país em que se situa à organização para a qual haja sido nomeado ou designado o servidor, não é exato?

- Sim, é o que dispõe o item III do artigo $2 .^{\circ}$ da Lei de Retribuição no Exterior.

\section{- Nesses casos, quem define a sede no exterior?}

- É definida para cada órgão ou servidor, conforme o caso, pelo respectivo Ministro de Estado.

Já que se falou em competência, é oportuno consignar 0 seguinte : a competência estabelecida para os Ministros de Estado no regulamento da Lei de Retribuição no Exterior é aplicável ao dirigente de órgão integrante da Presidência da República, ou a ela subordinado, quando se tratar de servidor de um desses órgãos.

No caso de servidor do Distrito Federal, dos Estados ou dos Municípios, bem como de pessoas sem vínculo com o serviço público, designados pelo Presidente da República, a competência estabelecida se refere ao Ministro a que estiver subordinada ou vinculada a missão ou atividade no exterior, salvo se declarada expressamente a competência no ato da nomeação ou designação. 
- Deve haver, assim, uma proposta de nomeação ou de designação de servidor, para serviço da União no exterior?

- Sim. E essa proposta deve indicar, em cada caso, o tipo e natureza da missão ou atividade; o período e os limites mínimo e máximo, previstos para sua duração, quando em missão transitória ou eventual; a obrigatoriedade, ou não, de mudança de sede, quando em missão transitória, bem como, afinal, a possibilidade, ou não, de fazer-se acompanhar de dependentes.

- E, no caso de pessoa sem vínculo com o serviço público, ou empregado público, ou funcionário sem nível de vencimentos previstos? Como fixar o índice?

- No caso de pessoa sem vínculo com o serviço público, nomeada ou designada pelo Presidente da República, ou empregado público, ou funcionário sem nível de vencimentos previsto, a proposta deve fixar um indice, dentre os constantes da Tabela de Escalonamento Vertical, anexa à Lei de Retribuição no Exterior, que mais se aproximar do cargo, função, emprego ou atividade que a pessoa vai desempenhar, o qual lihe será atribuído para efeito de retribuição no exterior e demais direitos.

Assim é que, baixado o ato de nomeação ou designação, o Ministro de Estado ou autoridade delegada deve enquadrar a missão em ato próprio, na forma anteriormente referida - isto é, com indicação de tipo e natureza da missão ou atividade etc. - - de modo que se possam definir a retribuição e direitos do servidor, no exterior, ou da pessoa sem vínculo com o serviço público.

rios, Essa lei revogou o artigo 120 do Estatuto dos Funcionáves, que definia remuneração no exterior, que correspondia ao vencimento do cargo acrescido da representação no Brasil. Como a Lei de Retribuição no Exterior definiu essa expressão?

De acordo com essa lei, considera-se retribuição no ex terior o vencimento de cargo efetivo para o funcionário público, ou o soldo para o militar, acrescido da gratificação e das indenizaÇões, previstas nesse diploma legal. No caso de servidor regido pela legislação trabalhista, considera-se retribuição no exterior o salário, acrescido das indenizações e, se for o caso, da gratificaÇão, previstas nessa lei. O parágrafo único do artigo 120 do Es. tatuto dos Funcionários foi expressamente revogado pela Lei $n$. 5.809 , de 1972 . 


\section{- Essa retribuição continua sendo em cruzeiro?}

- Não, a retribuição no exterior, em princípio, é fixada e paga em moeda estrangeira. Em missão eventual, o servidor em serviço no exterior continua a perceber a retribuição ou remuneração a que faz jus, em moeda nacional ou estrangeira, conforme o caso, na organização civil ou militar a que pertence. Também em casos especiais, em que o servidor pode ser designado para missão transitória, sem mudança de sede para o exterior, de duração de até 60 dias, o que não lhe dará direito à retribuição no exterior; nessa hipótese, o servidor recebe em moeda nacional, além da retribuição ou remuneração e demais vantagens a que fizer jus, a indenização diária em valor eqüivalente ao de uma diária de alimentação devida no País, além da alimentação e pousada que for assegurada pela União, bem como a ajuda-de-custo correspondente a um mês de vencimento, salário ou soldo, no País, quando em missão de representação, decorrente de compromissos internacionais.

Cabe notar que o servidor nomeado ou designado para missão eventual no exterior faz jus à retribuição, em moeda nacional cu estrangeira, que já venha recebendo regularmente, ao transporte e a diárias no exterior, na forma da Lei de Retribuição no Exterior e de sua regulamentação.

Cumpre assinalar, ainda, que a retribuição no exterior, em princípio, elimina o direito do servidor à percepção de vencimento, salário ou soldo, e quaisquer indenizações ou vantagens, em moeda nacional, que the possam ser devidas no período em que fizer jus àquela retribuição.

vários elementos?
Quer que a retribuição no exterior se integra de

- Sim, é constituída de 1) Retribuição básica : vencimento ou salário, no exterior, para o servidor civil, e soldo no exterior, para o militar; 2) Gratificação : Gratificação no Exterior por tempo de serviço; 3) Indenizações : a) Indenização de Representação no Exterior; b) Auxílio-Familiar; c) Ajuda-de-Custo de Exterior; d) Diárias no Exterior, e e) Auxílio-Funeral no Exterior.

parcelas somadas?

- Mas, não há um teto para isso, vale dizer, para essas

- Há. Salvo no caso dos Embaixadores-Chefes de Missão Diplomática brasileira junto a organismos internacionais, a soma R. Serv. públ., Brasília, 109 (1) Jan./mar. 1974 
dos valores da retribuição básica e da indenização de representação no exterior, percebida por qualquer servidor, não pode ultrapassar $90 \%$ da importância que, a igual título, é atribuída ao Chefe da Missão Diplomática brasileira acreditado junto ao governo do país em que o servidor estiver em serviço no exterior.

ber - De quando e até quando terá o servidor direito a percea retribuição?

na -O direito do servidor à retribuição no exterior tem início mento de embarque para o exterior e cessa na data do desligano to de sua sede no exterior ou da partida da última localidade no exterior, relacionada com sua missão. $E$ as datas de partida e de desligamento são determinadas ou aprovadas, conforme o caSo, pelas seguintes autoridades: a) quando se tratar de Ministros de Estado ou dirigente de órgão integrante da Presidência da República ou a ele subordinado - o Presidente da República; b) quando se tratar de servidor da Vice-Presidência da República o Vice-Presidente da República; c) quando se tratar de servidor de órgão integrante do respectivo Ministério, a ele vinculado ou sob sua supervisão - o Ministro de Estado ou autoridade com delegação de competência específica.

\section{- O que se considera como data de partida do País?}

para - Considera-se, em qualquer caso, data de partida do País de o exterior aquela em que o servidor deixar a última localidaem território nacional.

Com relação, ainda, à indagação anterior, cumpre esclareCer que o direito do servidor à retribuição no exterior cessa na data da partida da última localidade no exterior com sua missão nas seguintes hipóteses: a) missão desempenhada a bordo de havio ou aeronave militar em viagem ou cruzeiro de instrução; b) como comandante ou integrante de tripulação, contingente ou força, em missão operativa ou de adestramento; c) em missão transitória, seja de representação, de observação ou em organismos ou em reuniões internacionais, seja de encargos especiais; e d) em missão eventual.

\section{- E nos demais casos?}

sões - Nos demais casos de missões transitórias e nas misces permanentes, o direito do servidor à retribuição no exterior pela autoridade competente, conforme o caso. É de assinalar, ain 
da, que os Ministros de Estado, mediante autorização do Presidente da República, podem, em casos especiais, designar servidor para missão transitória de duração até 60 dias, sem direito à retribuição no exterior.

- Se um servidor que esteja em missão permanente entrar em férias ou casar-se ou ter que licenciar-se para tratamento de saúde, terá interrompida sua retribuição no exterior?

- Não. Esse pagamento não se interrompe em virtude de férias, de viagem ao Brasil a serviço, ou por motivo de núpcias, luto ou de licença para tratamento de saúde até noventa dias, bem como no caso de funcionária pública, em razão de licença para gestante. Também não se interrompe o pagamento quando se tratar de missão transitória, em virtude de viagem ao Brasil, a serviço.

exterior?

- Qual o conceito dado a vencimento, salário ou soldo no

- É a retribuição básica mensal devida ao servidor em serviço no exterior, em missão permanente, ou transitória, obedecido seu nível ou grau de hierarquia. Há Tabelas de Escalonamento Vertical com indices de retribuição básica.

Cabe notar que se aplicam ao vencimento e ao soldo no exterior as disposições legais e peculiares ao servidor quanto à penhora, ao seqüestro e ao arresto, bem como à suspensão temporária ou cessação de direito previstas para o vencimento ou soldo no País.

- O segundo elemento que integra o conceito de retribuição no exterior é a Gratificação no Exterior por Tempo de Serviço. Como foi definida essa gratificação?

- Gratificação no Exterior por Tempo de Serviço é o quantitativo devido ao servidor. em serviço no exterior, no desempenho de missão permanente ou transitória, por anos de efetivo serviço prestado, jả computados na forma da legislação pertinente.

\section{- E o terceiro elemento?}

-Trata-se das chamadas indenizações : a indenização de representação no exterior, o auxílio-familiar, a ajuda-de-custo de exterior, as diárias no exterior e, finalmente, o auxílio funeral no exterior. 
Vejamos a primeira delas :

\section{- A indenização de representação no exterior?}

- Sim. Essa indenização é o quantitativo devido ao servidor, em serviço no exterior, em missão permanente ou transitória, destinado a compensar as despesas inerentes à missão de forma compatível com suas responsabilidades e encargos.

sa indenização?

- Com base em que índices se há de calcular o valor des-

- De acordo com a lei, essa indenização se há de calcular com base em índices e fatores de conversão variáveis, estabelecidos em razão do grau de representatividade da missão; do tipo e natureza da missão; da correspondência entre cargos, missões e funções; da hierarquia funcional ou militar; do custo de vida local; das condições peculiares de vida da sede no exterior; e do desempenho cumulativo de cargos. Finalmente, para as missões a bordo de navios ou aeronaves militares, são considerados fatores de conversão regionais, com base nos estabelecidos para as localidades - sede ou localidades visitadas.

Segundo o regulamento, o valor da indenização de representação no exterior é calculado com base nas Tabelas de Escalonamento Vertical de Índices de Representação e de Fatores de Conversão de Índices de Representação.

O valor básico dessa indenização é encontrado multiplicando-se o índice de representação, que corresponda ao cargo, função ou atividade desempenhados no exterior, pelo fator de conversão determinado para a sede do servidor ou pelo fator de conversão calculado na forma do artigo 14 do Regulamento.

represental o critério de fixação dos índices de indenização de

- Os índices dessa indenização e seus fatores de conVersão serão estabelecidos em tabelas e expressos em unidades da moeda-padrão utilizada nas transações financeiras internaciohais do governo brasileiro. A matéria foi deferida ao regulamentador da lei dentro desses princípios, devendo o Poder Executivo, em decreto aplicável a todos os servidores abrangidos por essa lei, modificar referidas tabelas, quando se verificarem alterações dos elementos de fixação dos índices e seus fatores de conversão. 


\section{- Há possibilidade de se pagar mais de uma indenização} de representação no exterior?

- A regra é que, em qualquer situação, apenas uma indenização de representação será concedida ao servidor.

No caso de representação cumulativa, a indenização de representação no exterior, concedida ao chefe efetivo de Missão Diplomática e aos adidos militares, será acrescida de dez por cento de seu valor básico, por país adicional.

A mesma representação devida aos adidos militares, quando representantes de mais de uma Força, será acrescida de dez por cento, por Força adicional. O cálculo dos acréscimos, por país ou Força adicional, é feito sobre o valor básico da indenização de representação na sede da Missão Diplomática.

\section{- Deve haver alguma vantagem em casos de substituição?}

- Sim. Ocorrendo afastamento igual ou superior a trinta dias do Chefe efetivo da Missão Diplomática, do Adido Militar, do Chefe da Repartição consular e do Delegado do Tesouro Brasileiro no Exterior, seus substitutos têm direito a um suplemento mensal eqüivalente a trinta por cento da indenização de representação no exterior atribuída ao titular. O servidor receberá, a partir do primeiro dia da substituição, esse suplemento mensal.

\section{zação de representação?}

- Quando passar o cargo ou encerrar suas atividades em virtude do término da missão; quando ultrapassar trinta dias afas. tado do desempenho ou exercício do cargo, função ou atividade, salvo por motivo de férias, luto ou de licença para tratamento de saúde, e, no caso de funcionária, por motivo de licença para gestante; quando entrar em licença especial e, finalmente, quando cessar ou for suspenso seu direito ao vencimento ou ao soldo na forma da legislação vigente.

- Ainda sobre indenização de representação no exterior, que critério deverá ser adotado quando a Tabela do Anexo II náo indicar fator de conversão para a sede do servidor?

- Será adotado, então, respectivamente a) o fator de conversão atribuído à localidade no território do mesmo país que esteja assinalada na tabela com a sigla " $F C G$ " (fator de conversão 
geral); ou b) o fator de conversão 10 , se não houver fator de conversão geral para o território.

Vale notar que, ao ser criada organização, militar ou civil, da Administração Federal, no exterior, deverá ser determinado, Se já não existir, o fator de conversão correspondente à sede da organização e, se for o caso, o fator de conversão geral para o país.

litares?

- E no caso de missão a bordo de navio ou aeronave mi-

- Para missão a bordo de navio ou aeronave militares, o fator de conversão regional será a média ponderada dos fatores de conversão referentes às localidades visitadas, considerando-se como multiplicador o número de dias de permanência em cada uma.

\section{- Qual a autoridade que fixará o fator de conversão?}

- Para cada missão, o fator de conversão regional será previamente fixado pelo respectivo Ministro e inalterável para a missão, mesmo que alterados os prazos de permanência.

\section{- E nos casos de prorrogação?}

- Nos casos de prorrogação de missão, poderá ser fixado novo fator de conversão, aplicável somente ao período de prorrogação.

remoção ou movimentação?

- Nos casos de remoção ou movimentação no exterior, o Servidor passará a perceber, a contar da data de sua partida, a indenização de representação no exterior prevista para a nova missão.

É de observar que essa indenização de representação não pode ser objeto de desconto ou consignação, salvo quando a lei assim o determinar expressamente.

do - Vejamos, agora, outra espécie de indenização: o chama. Auxílio-Familiar.

\section{- É o mesmo Salário--Família?}

É uma espécie de edição revista e melhorada do Salário. Família. Sua definição é dada pelo legislador: é o quantitativo 
mensal devido ao servidor, em serviço no exterior, a título de indenização para atender, em parte, à manutenção e às despesas de educação e assistência, no exterior, a seus dependentes. Observe-se que o benefício é devido ao servidor, que é, assim, o titular do direito e não o dependente.

mília?

- Seu valor é fixado com o mesmo critério do Salário-Fa.

- Não. O auxílio-familiar é calculado em função da indenização de representação no exterior recebida pelo servidor à ra. zão de $10 \%$ de seu valor, para a esposa, e $5 \%$ de seu valor, para cada um dos seguintes dependentes: a) filho menor de 21 anos ou estudante, menor de 24 anos que não receba remuneração ou seja inválido ou interdito; b) filha solteira, que não receba remuneração; c) mãe viúva, que, igualmente, não receba remuneração; d) enteado, adotivo, tutelados e curatelados, menores de 21 anos ou estudantes menores de 24 anos que não recebam, também, remuneração, ou que sejam inválidos ou interditos; e) a mulher solteira, desquitada ou viúva, que viva, no mínimo, há cinco anos, sob a dependência econômica do servidor solteiro, desquitado ou viúvo, e enquanto persistir o impedimento legal de quaisquer das partes para se casar.

Cumpre notar que quando o servidor tiver de educar, fora do país onde estiver em serviço, os filhos, os enteados, os adotivos, os tutelados e os curatelados, atendidos aqueles requisitos anteriormente referidos, o auxílio-familiar será acrescido de um quantitativo igual a um trinta avos do maior valor de indenização de representação no exterior, atribuido a Chefe de Missão Diplo-
mática.

\section{lio-familiar?}

Com base em que deve ser feita a concessão do auxí

- Deve ser feita com base nos dados da declaração de dependentes do servidor, registrada e arquivada no órgão competente, observado estritamente o que dispõe a lei nesse sentido. Vale esclarecer que o servidor, quando no exterior, deve oficializar, por intermédio do órgão encarregado desses assuntos, as alterações que devam atualizar sua declaração de dependentes.

- Foram fixados limites ao regulamentador?

- Sim. Dispôs a lei que o regulamento deve estabelecer: a) o limite mínimo por dependente a ser observado no pagamen- 
to do auxílio-familiar, e b) os casos especiais que justifiquem o acréscimo do quantitativo na hipótese de o servidor ter que edu. car, fora do país onde estiver em serviço, os seus dependentes (filhos, enteados etc.). Impede considerar que o limite mínimo estabelecido do auxílio-familiar, por dependente, é igual a meio por cento da maior indenização de representação no exterior, deferida a Chefe de Missão Diplomática, não computados os percentuais concedidos no caso de representação cumulativa.

\section{- Será essa exclusão feita sempre?}

- Não. O servidor, em missão permanente ou transitória, cimuração igual ou superior a seis meses, tem direito ao acréscimo de um quantitativo igual a um trinta avos do maior valor de indenização de representação no exterior atribuído a Chefe de Missão Diplomática, quando tiver de educar, fora do país onde estiver em serviço, os filhos de qualquer condição. No caso de representação cumulativa, mais dez por cento do valor básico da indenização de representação no exterior, por país adicio-

de Cabe esclarecer que o Decreto $n .^{\circ} 72.288$, de 21 de maio 1973, estabeleceu os casos especiais que dão direito ao acréscimo do auxílio-familiar, publicando em anexo uma relação de países ou áreas para efeito de acréscimo, com duas listas A e B. De modo que um servidor em serviço na Albânia, na Argélia, na Bulgária, no Egito, na Hungria, no Iraque, na lugoslávia, na Líbia, na Polônia, na Romênia, na Síria, na Tchecoslováquia ou na RúsSia, terá direito ao acréscimo do auxílio-familiar à razão de dez por cento da indenização de representação no exterior para a esposa e de cinco por cento para os demais dependentes previstos na lei.

Nos países ou áreas constantes da lista B - Afganistão, Angola, Barbados, Bolívia, República da China, Chipre, CingapuEl Coréia do Sul, Costa do Marfim, Costa Rica, Coveite, Daomé, El Salvador, Etiópia, Filipinas, Gana, Guatemala, Guiana, Guiana Francesa, Haiti, Honduras, Indonésia, Irã, Islândia, Jamaica, Jordânia, Malásia, Mali, Marrocos, Mauritânia, Moçambique, Nicarágua etc. - - o acréscimo só será concedido quando, em relação ao nivel de escolaridade e área de especialização do dependente, houver insuficiência de estabelecimentos de ensino.

ção Diz, ainda, referido decreto que, nos casos de representaa cumulativa, só será considerado o país onde está situada 
do acréscimo?

- Em que época e quais os requisitos para a concessão

- O acréscimo do quantitativo é concedido, durante os meses do ano letivo, mediante apresentação de prova de matrícula do dependente em estabelecimento de ensino, fora do país onde está a sede do servidor no exterior.

- Os casos especiais que justifiquem o acréscimo em que serão baseados?

- Tais casos especiais, como vimos, serão estabelecidos em decreto específico, e a seleção dos locais, áreas ou países, a serem considerados como casos especiais que justifiquem aquele acréscimo do quantitativo, deve basear-se, exclusivamente, na possibilidade de prejuízo à formação profissional e ideolóqica do dependente.

Vale, por derradeiro, notar que se os dependentes permanecerem no Brasil, o beneficio pago ao servidor será o saláriofamília e não o auxílio-familiar.

to de Exterior.

Outra espécie de indenização é a chamada Ajuda-de-Cus-

\section{- Qual seu conceito legal?}

- Ajuda-de-custo de exterior é a indenização paga, adiantadamente, ao servidor para custeio das despesas de viagem. de mudança e da nova instalação.

\section{terior?}

- Quando é que o servidor faz jus à ajuda-de-custo de ex-

- Na hipótese de missão permanente, quando a remoçăo ou a movimentação importarem em mudança de sede concomitante ao desligamento da organização onde exerce suas ativi: dades. Ainda em missão permanente ou transitória, quando deslocado com a sua organização, ao ser transferida de sede, desde que não seja em caráter periódico. Na hipótese de missão transitória, quando a remoção ou a movimentação importarem em mudança de sede : a) com desligamento de sua organiza. ção, por prazo igual ou superior a seis meses; b) com ou sem desligamento de sua organização, por prazo inferior a seis me-

4. Parecer da COLEPE (DASP) no Processo $1.252 / 72$ - Diário Oficial de 23 de abril de 1973. 
ses e superior ou igual a três meses; e c) com ou sem desligamento de sua organização, por prazo inferior a três meses. - E se acontecer de ser o servidor, independentemente
do sua vontade, afastado em definitivo da missão para a qual foi designado, sem que o prazo previsto haja decorrido?

- Tem ele direito à ajuda-de-custo de exterior no valor estabelecido para a missão para a qual foi designado.

pendentes?

- E, no caso de morte do servidor, como ficam os de-

- Os dependentes do servidor falecido em serviço no exterior com direito à ajuda-de-custo fazem jus a seu recebimento para regresso ao Brasil, nos valores previstos na Lei de Retribuição no Exterior, na situação em que estivesse ao falecer.

\section{- Qual o valor da ajuda-de-custo de exterior?}

- Tem o valor de duas vezes a retribuição básica e duas vezes o auxílio-familiar, acrescido o total de uma indenização de representação no exterior a que o servidor tiver direito na nova sedè no exterior, observados os valores em vigor à data determinada para a partida. Se se tratar de remoção ou movimenta. ção para o Brasil, a ajuda--de-custo deverá ser calculada nessas mesmas condições, porém com base nos valores relativos à sede no exterior.

\section{- Como é paga essa ajuda-de-custo?}

te - É paga integralmente, nos casos de missão permanen, quando a remoção ou a movimentação importarem em mudança de sede concomitante ao desligamento da organização onde exerce o servidor suas atividades; nos casos de missão perma. nente ou transitória, quando deslocado o servidor com a sua organização, ao ser esta transferida de sede, desde que não seja em caráter periódico; e, no caso de missão transitória, com desligamento de sua organização, por prazo igual ou superior a seis meses, quando a remoção ou a movimentação importarem em mudança de sede. É paga pela metade de seu valor, no término dela, no caso de missão permanente, quando a remoção ou a movimentação importarem em mudança de sede concomitante ao desligamento da organização onde exerce o servidor suas atividades, quando já tiver recebido ajuda-de-custo de exterior em seu valor integral há menos de dois anos, e, no caso de mis- 
são transitória, quando a remoção ou a movimentação importarem em mudança de sede, com ou sem desligamento de sua organização, por prazo inferior a seis meses e superior ou igual a três meses. É paga pela quarta parte de seu valor, no início da missão, e pela oitava parte de seu valor, no término dela, nos casos de missão transitória, com ou sem desligamento de sua organização, por prazo inferior a três meses.

\section{- Ainda que o servidor seja removido a pedido fará jus
ajuda-de-custo de exterior?}

- Não. Não tem direito à ajuda-de-custo de exterior 0 servidor removido ou movimentado a pedido, e de sede no exterior para o Brasil, a fim de entrar em licença, a qualquer título, bem como o que for desligado de curso ou estabelecimento de ensino, por trancamento voluntário de matrícula.

- Se o servidor, por qualquer eventualidade, deixar de seguir para o exterior a serviço, deverá restituir a ajuda-de-custo?

- Quando deixar de seguir destino, a pedido, deverá restituir, de uma só vez, e integralmente, a ajuda-de-custo de exterior; quando isso acontecer por motivo independente de sua vontade, deverá restituir com redução das despesas comprovadamente feitas. Deverá, ainda, restituir, mas pela metade do valor recebido, quando, até seis meses após ter seguido destino, for c servidor dispensado a pedido, exonerado, aposentado, transferido para a reserva ou demitido.

- Mas, haverá hipótese em que a ajuda-de-custo de exterior não deverá ser restituída?

- Sim, se após haver o servidor seguido destino for mandado regressar. Se ocorrer seu falecimento, após havê-la recebido, os herdeiros do servidor não estão obrigados a restituir a ajuda. A restituição ficará, assim, à discrição da família do servidor extinto.

Esclareça-se, por fim, que essa ajuda-de-custo deve ser concedida uma única vez, em cada remoção ou movimentação com mudança de sede, e na forma que vimos, isto é, nos termos dos artigos 23, 24 e 25 da Lei de Retribuição no Exterior.

- O servidor designado para missão no Exterior faz jus, naturalmente, a transporte?

- Sim, tem direito a transporte por conta do Estado, sendo que na expressão transporte estão compreendidas a passa.

R. Serv. públ., Brasília, 109 (1) jan./mar. 1974 
gem e, conforme o caso, translação da bagagem do servidor e dos seus dependentes, e até mesmo de empregado doméstico.

transporte?

\section{Quais as condições e forma por que é assegurado o}

- É assegurado na forma e condição seguintes: 1) passagem via aérea, para o servidor e seus dependentes, bem como translação de bagagem, quando designado para missão permanente ou missão transitória de duração superior a seis meses, com mudança de sede, e missão transitória, com mudança de sede, de duração inferior a seis meses e igual ou superior a três meses, com dependentes; 2) passagem via aérea para o servidor, sua espôsa e dependentes menores quando for desig. nado para exercício, em caráter provisório, de missão considerada permanente e cuja duração seja superior a trinta dias; e 3) passagem via aérea para o servidor, quando designado para missão transitória ou missão eventual.

Na primeira hipótese, com mudança de sede, de duração inferior a seis meses e igual ou superior a três meses, sem dependentes. Na hipótese de missão transitória, sem mudança de sede e de duração igual ou superior a três meses, ou com mudança de sede ou mesmo sem mudança de sede, se essa missão for de duração inferior a três meses. Parece claro que, para a missão eventual, a passagem via aérea só é assegurada ao servidor.

E assegurado, ainda, o transporte, na forma e condições Seguintes: a) para um empregado doméstico, quando designado o servidor para missão permanente ou transitória com mudança de sede; b) anualmente, no período mais longo de férias escolares, passagens via aérea que possibilitem aos dependentes reunirem-se à família na sede no exterior onde o servidor se encontrar em missão permanente ou transitória, se estiver educando, fora do país onde estiver em serviço, os seus dependentes (filhos, enteados, adotivos, tutelados e curatelados) que lhe ensejam o auxílio-familiar; c) passagem via aérea, para o servidor e seus dependentes, quando, em área de condições peCuliares, tiver direito, na forma da legislação aplicável, à vinda Periódica ao Brasil, e diplomata da classe final ou semi-final da Carreira, vier ao Brasil em gozo de férias extraordinárias; d) duas passagens via aérea, quando a sede no exterior não dispuser de assistência médico-hospitalar apropriada e, comprovadamente, dela necessitar, em caráter urgente, o servidor ou seus 
dependentes, e, finalmente, e) passagens via aérea para o servidor, quando chamado a serviço ao Brasil.

utilizar - Bem, mas não poderá acontecer que seja necessário utilizar outro tipo de transporte que não o aéreo?

- Sim, caso seja necessário utilizar transporte diferente do aéreo, no todo ou em parte, para alcançar o local de destino, deverão ser fornecidas as correspondentes passagens por ferrovia, rodovia ou aquavia. No caso de missão permanente ou missão transitória de duração superior a seis meses, com mudança de sede, o servidor poderá optar por outro meio de transporte. desde que o valor das passagens não ultrapasse o das por via aérea. No caso de opção por outros meios de transporte que não os previstos na lei, as passagens serão requisitadas somente mediante cobertura prévia da diferença pelo servidor, quando o transporte pelo meio escolhido for de custo superior ao aéreo. Cabe notar que o servidor não tem direito a recebimento da diferença quando o custo do transporte pelo meio escolhido for inferior ao do transporte aéreo concedido.

\section{segurado 0 transporte.}

- 0 transporte só é assegurado àqueles que constarem da declaração de dependentes do servidor Em caso de falecimento do servidor, esses mesmos dependentes fazem jus a transporte para regresso ao Brasil. Quando o servidor falecer em serviço no exterior, os dependentes constantes de sua decla ração têm direito, dentro do prazo de um ano, contado da datí do falecimento, ao transporte para regresso ao Brasil, obedeci. das as disposições sobre passagens e bagagens, para dependen. tes, estabelecidas no Regulamento, inclusive o limite de cubagem e de peso a que tinha direito o servidor falecido.

- E se o servidor tor movimentado a pedido, terá direito a transporte para o Brasil?

- Não tem direito a transporte o servidor removido ou movimentado, a pedido, e de sede no exterior para o Brasil, a fim de entrar de licença, a qualquer título, bem como o participante de viagem ou cruzeiro de instrução, e o comandante ou integrante de tripulação, contingente ou força, em missão operativa ou de adestramento em país estrangeiro. 
igual ou superior a três meses, com dependentes, e em fatores $\mathrm{R}$, equivalentes à retribuição básica de chefe de Missão Diplomática, de acordo com as tabelas que constituem o Anexo $\mathrm{V}$ do Regulamento - Decreto $n .^{\circ} 71.733$, de 18 de janeiro de 1973 , para as missões permanentes ou transitórias de duração superior a seis meses, com mudança de sede.

\section{- Mas, poderá o servidor solicitar complementação?}

- Não. Em nenhum desses casos, antes referidos, poderá o servidor solicitar complementação de importância em dinheiro para atender aos limites fixados, caso não os alcance.

\section{- O transporte é somente para o servidor?}

- Não. Já tivemos oportunidade de dizer que o Ministério ou órgão responsável pelo deslocamento deverá providenciar - transporte do servidor nomeado ou designado para servir no exterior, e, quando for o caso, de seus dependentes e de empregado doméstico bem como de sua bagagem, na forma estabelecida no referido Decreto $n .^{\circ} 71.733$, de 1973.

\section{- Quem requisita as passagens?}

- As passagens, via aérea, para o servidor, dependentes, empregado doméstico e bagagem são requisitadas pelo órgão competente; o mesmo acontecerá com relação aos transportee em geral. As requisições devem ser feitas pelo órgão competente diretamente às empresas do ramo, sem interferência, direta ou indireta, de agentes ou intermediários.

\section{- As passagens são sempre em primeira classe?}

em classe turística ou econômica.

Em primeira classe ou equivalente : para os militares, quando Oficial-General, Capitão-de-Mar-e-Guerra ou Coronel; para os funcionários e empregados públicos com nível de vencimento previsto, quando de nível superior ao de Primeiro-Secretário, e para os demais servidores e pessoas sem vínculo com o Serviço público, designados pelo Presidente da República, quando o índice de vencimento para eles fixado for superior ao de Primeiro-Secretário.

Em classe turística ou econômica : para os demais servidores e pessoas não constantes do item anterior, e para o em- 


\section{- Quais as providências afetas ao Ministério ou órgão} a que pertence o servidor designado para missão no exterior?

- O Ministério a que pertence o servidor designado para missão no exterior providenciará as passagens e translação da bagagem de ida e volta, com pagamento em moeda nacional, se a missão é de duração igual ou inferior a seis meses; de ida, com pagamento em moeda nacional, e de volta, em moeda estrangeira, se a missão é de duração superior a seis meses; com pagamento em moeda estrangeira, quando já se encontra o servidor em outra missão no exterior.

\section{- Quais os limites de cubagem e de peso da bagagem} do servidor que podem ser compreendidos no transporte?

- O legislador deferiu o assunto para o regulamentador. Os limites de cubagem e de peso, para efeito de translação de bagagem, estão fixados nas tabelas que constituem o Anexo IX do decreto regulamentador da Lei de Retribuição no Exterior. Além dos limites de cubagem e de peso fixados, o servidor tem direito a um acréscimo de um metro cúbico ou duzentos quilos, por dependente, nas missões de duração igual ou superior a três meses e inferior a seis meses; de dois metros cúbicos ou quatrocentos quilos, por dependente e pelo empregado doméstico, nas missões de duração igual ou superior a seis meses; $e$ dos metros cúbicos ou quilogramas necessários ao transporte terrestre ou marítimo de um automóvel de sua propriedade. Vale notar que o servidor, com mais de dois anos de serviço nu exterior, admitidas somente as interrupções constantes do $\S 2$. do artigo 10 da Lei de Retribuição no Exterior, faz jus a um acréscimo de $5 \%$ do peso ou cubagem totais a que tiver direito, para cada ano além daquele prazo. Essas interrupções, como dissemos, são as que ocorrerem em virtude de viagem ao Brasil a serviço, em férias, por motivo de núpcias, luto ou de licença para tratamento de saúde até noventa dias e, para a funcionária pública, licença para gestante, isso no caso de missão permanente. Na hipótese de missão transitória, em virtude de viagem ao Brasil a serviço.

\section{- Qual o valor máximo da avaliação dos bens do servi-
para efeito de seguro?}

- Para efeito de seguro, a valor é fixado em duas vezes a retribuição básica do próprio servidor, para as missões transitórias, com mudança de sede e duração inferior a seis meses e 
pregado doméstico do servidor que o acompanhar durante a missão de período igual ou superior a seis meses.

Cumpre notar que o transporte aéreo de pessoal do Brasil para o exterior e vice-versa, ou entre localidades no exterior, deve ser feito mediante requisições a empresas nacionais, salvo no caso de ausëncia de conexões.

- E quando não houver possibilidade de transporte aéreo, como deverá proceder o órgão competente?

- Na seleção dos meios e vias de transporte, o Ministério ou órgão responsável pelo deslocamento deverá, então, levar em conta os seguintes aspectos : a) economia para a União; b) tarifas oficiais vigentes; c) natureza e tipo da missão para a qual o servidor houver sido nomeado ou designado; d) nível hierárquico, funcional ou militar, do servidor; e) existência, ou não, de linhas de transporte marítimo, ferroviário ou rodoviário, diretas; f) urgência de chegada à localidade de destino; g) possibilida. de de utilização dos meios de transporte oficiais ou próprios; h) existência de transporte assegurado por Estado estrangeiro ou organismo internacional; e i) existência de opção entre diferentes classes no meio de transporte a utilizar.

- E o transporte da residência do servidor ao aeroporto ou deste à localidade-sede da missão por conta de quem fica?

tes - Considerando esses mesmos aspectos que vimos antes, o transporte entre o terminal aéreo no exterior e a localida. de-sede da missão do servidor, e vice-versa, será a ele indenizado, mediante apresentação dos comprovantes da respectiva despesa.

\section{- E a taxa de seguro?}

- Também será paga pelo Ministério ou órgão a que o servidor estiver vinculado para fins da missão que irá exercer ou exerce. De modo que será assegurado ao servidor a translação, terrestre ou marítima, da respectiva bagagem, de porta a porta, incluindo embalagem, desembalagem e seguro, cabendo aos referidos órgãos efetuar o pagamento dessas despesas diretamente à empresa responsável.

- Se um servidor tiver uma missão que dure mais de três meses, gozará de alguma vantagem especial quanto ao peso da sua bagagem? 
- Sim. Nas viagens de ida para o exterior, por via aérea, em missão permanente, ou transitória, igual ou superior a três meses, poderá ser concedido ao servidor e seus dependentes um adicional de até a metade do peso da bagagem acompanhada.

- Se um servidor necessitar para si ou para um de seus dependentes de assistência médico-hospitalar e se essa assistência for impossível na sede ou mesmo não existir?

- Ser-lhe-á concedido, ao servidor ou a seus dependentes, transporte quando a sede no exterior não dispuser de assistência médico-hospitalar apropriada e, comprovadamente, se se fizer ela necessária, em caráter urgente. Nesse caso, cabe ao Ministro de Estado, ou autoridade delegada, autorizar a concessão desse transporte.

Vejamos, agora, as diárias para o servidor em serviço no exterior. Constituem elas elementos que integram a chamada retribuição no exterior.

Cabe observar, de logo, que as diárias no exterior contamse pelo número de dias correspondentes à missão eventual para a qual foi nomeado ou designado o servidor, incluindo-se também os dias da partida e da chegada.

\section{- Qual o conceito legal de diária no exterior ?}

- Diária no exterior é a indenização paga adiantadamente ao servidor para custeio das despesas de alimentação, de pousada e outras decorrentes do afastamento de sua sede, por motivo de serviço no exterior.

\section{- O valor dessas diárias varia ?}

- Sim. O valor da diária no exterior de Embaixador, Almirante-de-Esquadra, General-de-Exército ou Tenente-Brigadeiro, é igual a $4 \%$ da respectiva retribuição básica. Já com referência a Ministro de Estado, o valor da diária no exterior é igual a $125 \%$ da máxima retribuição básica. Para os demais servidores públicos, o valor da diária no exterior é fixado em percentagens da atribuída a Embaixador, Almirante-de-Esquadra, General-de-Exército ou Tenente-Brigadeiro, de acordo com as tabelas constantes do Anexo III do Decreto n. 71.733 , de 1973. Atentar que, no cálculo do valor da diária no exterior, são desprezadas as frações de unidade da moeda-padrão. Notar, ainda, que o valor dessas diárias 
é fixado pelo Poder Executivo, em decreto que se aplica a todos os abrangidos pela Lei de Retribuição no Exterior.

- Pode acontecer que um servidor, em serviço no exterior, precise vir ao Brasil em objeto de serviço; faria jus a diárias, e, no caso positivo, em que base?

- Sim, receberá diárias "em moeda nacional", de acordo com a legislação específica, no valor que, no País, é atribuído a seu posto ou graduação, cargo ou emprego efetivos ou àquele cujo nível de vencimento ou salário Ihe foi fixado, bem como, ao regressar, entre a data da partida da última localidade no exterior, relacionada com sua missão, e da chegada à primeira localidade no exterior.

Vale notar, ainda, que o servidor, em serviço no exterior, percebe diárias "em moeda nacional", na forma da legislação específica, no período em que permanecer no Brasil em objeto de serviço.

\section{no exterior?}

- Haverá ocasião em que o servidor não fará jus à diária

- Sim. Não tem o servidor direito à diária no exterior quando a alimentação e a pousada forem assegurados pelo Estado, e cumulativamente com a ajuda-de-custo de exterior.

sede ? - E se não ocorrer, por qualquer motivo, o afastamento da

exterior 0 servidor deverá restituir, integralmente, as diárias no denter, quando não ocorrer o afastamento da sede, e corresponsedes aos dias que ultrapassarem o período de afastamento da to. Nerviço, quando esse afastamento for menor que o previs. radas hipótese de que a alimentação e a pousada forem asseguno exterior.

deirosora, essas diárias não precisam ser restituídas pelos her-

Agora, essas diárias
do servidor falecido.

titui Vimos, então, que a chamada retribuição no exterior é constituída de retribuiçã̃o básica, gratificação e indenizações. Nestas. São incluídas a indenização da representação no exterior, o auxílio-familiar, a ajuda-de-custo de exterior, as diárias no exterior e, finalmente, o auxílio-funeral no exterior. 


\section{- Só nos falta ver o auxílio-funeral no exterior!}

- Exatamente. O Estado assegura sepultamento condigno ao servidor em serviço no exterior. O auxílio-funeral no exterior e o quantitativo destinado a atender às despesas com o funeral do servidor em serviço no exterior, em missão permanente ou transitória. Tem o valor da retribuição mensal que o servidor recebia normalmente no exterior, e é pago, de imediato, a quem de direito, mediante simples apresentação do atestado de óbito.

\section{- E se ninguém reclamar o pagamento ?}

- Decorridos trinta dias sem reclamação do auxílio-funeral no exterior por quem haja custeado o sepultamento do servidor. o auxílio será pago aos beneficiários da pensão, mediante requerimento à autoridade competente.

- E no caso de falecimento de servidor em serviço no exterior, em missão eventual ?

- Também nesse caso a União custeia e promove o sepultamento ou trasiada o corpo para o Brasil. Nesta hipótese, isto é, de transporte do corpo para o Brasil, o auxílio-funeral devido no País é pago em moeda nacional, observadas as disposições legais aplicáveis.

- E se a União custear diretamente o sepultamento do servidor falecido em serviço no exterior?

- Em casos especiais, a critério do Poder Executivo, a União pode custear diretamente o sepultamento, hipótese em que não sabe direito a qualquer tipo de auxílio-funeral por parte dos beneficiários do servidor falecido.

- E se o servidor faleceu no exterior e não estava ele acompanhado do cônjuge ou de parente adulto ?

- Ocorrendo o falecimento do servidor em serviço no exterior, não estando ele acompanhado do cônjuge ou de parente adulto, é assegurado a um membro de sua família o transporte de ida e volta até o local onde se encontrar o corpo.

- Pode acontecer de morrer um dependente no exterior ou até um empregado doméstico!

- Sim. Falecendo, no exterior, dependentes ou empregado doméstico do servidor, cujo transporte haja sido pago pela União, 
traslado do corpo para o Brasil será custeado pelo órgão a que está vinculado o servidor.

\section{- E o problema de desembaraço de bagagem ?}

- Os dependentes do servidor, falecido quando em serviço no exterior, têm direito ao mesmo tratamento aduaneiro para o desembaraço de bagagem que the era assegurado ao término de sua missão.

- Quais os órgãos responsáveis pelas providências para sepultamento, pagamento de auxílio-funeral e traslado do corpo ?

- São responsáveis por essas providências e conforme o caso os seguintes órgãos: a) a organização brasileira em que estava em serviço o servidor; b) a repartição consular em cuja jurisdição ocorrer o óbito; ou c) a Missão Diplomática no país, na inexistência das outras duas responsáveis.

Façamos, agora, algumas observações finais.

Reza o Decreto $\mathrm{n} \cdot{ }^{\circ} 71.733$, de 1973 , que o vencimento ou salário e o soldo no exterior são pagos de acordo com o disposto no artigo 14 da Lei de Retribuição no Exterior e de seu parágrafo único, e que gratificação no exterior por tempo de serviço é devida na forma do artigo 15 daquele diploma legal.

Como vimos, o vencimento ou salário e o soldo, no exterior, são pagos de acordo com as Tabelas de Escalonamento Vertical que acompanham referida lei. E o fator de conversão dos índices de retribuição básica é o quantitativo em cruzeiros equivalente a vinte unidades da moeda-padrão utilizada nas transações financeiras internacionais do governo brasileiro.

\section{tem - Quer dizer, então, que a Lei de Retribuição no Exterior tabelas !}

to - Sim, anexas a essa lei há duas tabelas de escalonamento vertical, com os índices de retribuição básica, de acordo com o artigo 14. A tabela I se refere a servidores civis. A tabela II se refere a militares.

Vale esclarecer que os proventos de aposentadoria do funCionário público e os de inatividade do militar continuam a ser calCuladas de acordo com a respectiva legislação específica, baseados unicamente na retribuição ou remuneração no País, neles não 
cevendo ser computadas as somas recebidas, a qualquer título, quando em serviço no exterior.

- E as contribuições para benefício de família?

- Continuarão a ser calculadas de acordo com a legislação específica, considerando-se, para esse fim, os valores dos descontos efetuados no País.

Dentro desses mesmos critérios, serão calculadas as pensões devidas aos beneficiários dos servidores que prestam ou hajam prestado serviço no exterior.

- E os descontos ou consignações que incidam sobre a retribuição do servidor?

- Os descontos ou consignações, obrigatórios ou facultativos, que incidam sobre a retribuição do servidor em serviço no exterior, em missão permanente ou transitória, são processados na forma estabelecida na regulamentação, isto é, de acordo com as disposições legais aplicáveis no País, conforme instruções baixadas pelos respectivos Ministros de Estado. Ressalvados os casos previstos em lei, de descontos obrigatórios a favor da Fazenda Nacional, em moeda estrangeira, é facultado ao servidor efetuar antecipadamente, em moeda nacional, o recolhimento dos demais descontos de consignações, diretamente ao órgão competente do respective Ministério.

- Há alguma coisa com referência a militar em serviço no exterior quanto a planos de provas das atividades especiais de vôo em aeronave militar ou salto em pára-quedas ?

- Sim. São assegurados, de acordo com a Lei de Remuneração dos Militares, ao militar em serviço no exterior que realizar exercícios ou cumprir missões previstas, no todo ou em par$t \epsilon$, nos planos de provas das atividades especiais de vôo em aeronave militar, salto em pára-quedas, imersão em submarino ou mergulho com escafandro ou com aparelho, o registro e a apreciação, para fins de homologação, de percepção ou de atualização de quotas de indenização de compensação orgânica a serem consideradas para pagamento, em moeda nacional, a partir da data de regresso ao território nacional, bem como, ao militar em campanha no exterior, a remuneração e demais direitos previstos naquele diploma legal. 
- No caso de Embaixadores não integrantes da carreira diplomática, como é fixada sua retribuição básica?

- A retribuição básica dos Embaixadores não integrantes da carreira diplomática, dos Ministros para Assuntos Comerciais de primeira e segunda classes e Cônsules Privativos é fixada de acordo com os índices da Tabela de Escalonamento Vertical que acompanha a Lei de Retribuição no Exterior, e a que já nos referimos ( $n .^{\circ}$ I) que é a concernente a Servidores Civis. De modo que - Embaixador não integrante da carreira diplomática tem o índice 100, o mesmo atribuído a Ministro no exercício do cargo de Embaixador; o Ministro para Assuntos Comerciais de primeira classe é igual ao Ministro de primeira classe, cujo índice é 94 . Já o Ministro para Assuntos Comerciais de segunda classe tem o índice 88, igual ao do Ministro de segunda classe, e o Cônsul Privativo tem 0 índice 46.

O critério de fixação é o mesmo quanto à retribuição das pessoas sem vínculo com o serviço público designadas pelo Presidente da República, observando-se os fatores estabelecidos para a indenização de representação no exterior: grau de representatividade da missão, tipo e natureza da missão, correspondência entre cargos, missões e funções, hierarquia funcional ou militar. Igual critério é ainda aplicado ao funcionário público, cujo cargo não tenha nivel de vencimento previsto no atual Sistema de Classificação de Cargos do Serviço Civil do Poder Executivo, bem assim ao empregado público, regido pela legislação trabalhista.

- Com esse critério legal novo como ficaria o servidor que tinha situação de remuneração diferente?

- É assegurada ao servidor público em serviço no exterior, enquanto permanecer na atual missão, retribuição mensal, no mínimo, igual à retribuição ou remuneração a que tinha direito a $10^{\circ}$ de janeiro de 1973 , isto é, na data da entrada em vigor da Lei de Retribuição no Exterior.

É de notar que o pagamento da retribuição no exterior deVerá ser previamente registrado pelo órgão pagador, na respectiva Guia de Pagamento no Exterior, de modelo estabelecido pelo $\mathrm{Mi}$ nistério da Fazenda, obedecidas as disposições da Lei de RetribuiCão no Exterior e de seu Regulamento, o Decreto $n .^{\circ} 71.733$, de 18 de janeiro de 1973 .

na regulamentação da lei ? 
- A revisão dos critérios estabelecidos no Decreto n. 71.733 , de 1973 , e em seus anexos, será efetuada, na forma da Lei de Retribuição no Exterior, após estudo conjunto pelo EstadoMaior das Forças Armadas e Ministérios da Fazenda, Relações Exteriores e Planejamento e Coordenação Geral, por iniciativa do Estado-Maior das Forças Armadas ou de qualquer desses Ministérios. Do mesmo modo se fará quando se tornar necessária a revisão dos anexos do Regulamento, por motivo de criação, transformação ou transposição de cargos.

Por derradeiro, cabe observar que, por essa legislação, foram especificamente revogados os Decreto-leis $n .^{\circ} \mathrm{s} 7.410$, de 23 de março de 1945; n. 995 , de 21 de outubro de 1969 e n. 1.227 , de 28 de junho de 1972; os parágrafos $2 .^{\circ}$ e $3 .^{\circ}$ do artigo 15 e os artigos 17, 18 e 19 do Decreto-lei n. 9.202, de 26 de abril de 1946; o artigo 48 da Lei $n .^{\circ} 488$, de 15 de novembro de 1948; 0 parágrafo único, do artigo 120 , da Lei $n .^{\circ} 1.711$, de 28 de outubro de 1952; o artigo 40, o parágrafo único do artigo 41 e o artigo 50 da Lei n. 3.917, de 14 de junho de 1951; o artigo 19 e seus parágrafos, da Lei n. 4.242, de 17 de julho de 1963 e o artigo 9. e seu parágrafo único, do Decreto-lei n. ${ }^{\circ} 310$, de 28 de fevereiro de 1967, e demais disposições legais que contrariem a matéria regulada pela Lei de Retribuição no Exterior - Lei $n .^{\circ} 5.809$, de 10 de outubro de 1972.

Vejamos outra espécie de afastamento para o exterior...

\section{- O do funcionário em razão de bolsa-de-estudo ?}

- Sim, em razão de bolsa-de-estudo ou desempenho de atividades com vistas a seu aperfeiçoamento funcional. Sabemos que, pelo artigo 37 do Estatuto dos Funcionários, não poderá 0 funcicnário ausentar-se do País, para estudo ou missão oficial, sem autorização do Presidente da República, e que essa ausência não excederá de quatro anos, sendo que, finda a missão ou estudo, somente decorrido igual período será permitida nova ausência. O Decreto n. $^{\circ} 61.775$ de 24 de novembro de 1967 , que dis põe sobre o afastamento de Servidores Públicos Federais para 0 exterior, reporta-se a esse preceito estatutário, aduzindo, em seu artigo 1. , que os afastamentos de funcionários públicos federais para o exterior somente serão autorizados, de acordo com o artigo 37 da Lei $n .^{\circ} 1.711$, de 28 de outubro de 1952, quando relativos a

\section{I - missão oficial do Governo;}


II - bolsa-de-estudo sobre assunto diretamente vinculado às atribuições do cargo ocupado pelo funcionário; e

III - desempenho de outras atividades tendentes ao seu aperfeiçoamento funcional.

Missão oficial do Governo seria o que a Lei de Retribuição no Exterior chama de afastamento a serviço da União.

- Nessas duas últimas hipóteses o afastamento fica conicionado a que ?

- Fica condicionado ao interesse da Administração. Não raro, essas viagens são feitas de acordo com programas de aperfeiçoamento e especialização, ou considerando a conveniência do estudo de determinados assuntos ou execução de determinado trabalho de interesse da Administração.

\section{- Esse afastamento será com ônus para os cofres públicos?}

- Em princípio, poderá ser permitido sem ônus para os coTús públicos ou, dependendo das disponibilidades orçamentárias específicas, com a concessão de ajuda-de-custo e outras vantagens, desde que haja interesse da Administração. Quando se tratar de afastamento com ônus para os cofres públicos, a competência continua sendo privativa do Presidente da República.

Impede notar que as viagens para missão ou estudo no estrangeiro, com ônus ou sem ônus para os cofres públicos, somente serão permitidas em casos excepcionais, a juízo do Presidente da República, de conformidade com o disposto no Decreto n. 67.494 , de 6 de novembro de 1970. Deverá haver, assim, prévia e expressa autorização do Presidente da República. De modo que a delegação de competência contida na letra $\mathbf{b}$ do artigo $10^{\circ}$ do Decreto n. 60.740, de 23 de maio de 1967 , está revogada.

ape Quais as instituições que organizam os programas de perfeiçoamento e especialização ?

O DASP com a colaboração dos Ministérios, consoante o aindelecido no Decreto-lei $n .^{\circ} 7.729$, de 12 de julho de 1945, inda em vigor. $\mathrm{E}$ os programas deverão ser anuais.

tabe Cabe notar que o referido Decreto-lei n. 7.729 , de 1945, estrelece normas para viagens de servidores civis da União ao es. acordo a se processarem assim: 1) sistematicamente, de acordo com programas anuais de aperfeiçoamento e especializa- 
ção; 2) efetivamente, tendo em vista a conveniência : a) do estudo de determinados assuntos de interesse da administração pública; b) da execução de determinado trabalho e c) do aproveitamento de bolsas-de-estudo oferecidas por instituições nacionais e estrangeiras.

- A que está sujeito o funcionário selecionado para se aperfeiçoar no estrangeiro?

- Está sujeito ao cumprimento do programa de atividades.

- No caso de bolsa-de-estudo ou desempenho de outras atividades que digam respeito ao aperfeiçoamento funcional, existe alguma condição para o afastamento ?

- Sim. O afastamento, nesses casos, fica condicionado ao interesse da Administração, e não será autorizado quando se tratar de interino ou funcionário em estágio probatório, mesmo que se trate de funcionário que, em regime de acumulação permitida pela Constituição, seja efetivo ou vitalício em um dos cargos.

- Por que não se autoriza o afastamento ao interino ou ao funcionário em estágio probatório?

- O afastamento do funcionário em estágio probatório di ficultaria a observação funcional a que está sujeito. Quanto ao interino, não poderá, igualmente, afastar-se da repartição onde foi inicialmente lotado isto porque a interinidade só se justifica para atender a inadiáveis necessidades de determinado órgão da Admi. nistração.

- Se o funcionário obtiver permissão para afastar-se para c exterior sem ônus para os cofres públicos, deixará ele de per. ceber vencimentos e demais vantagens permanentes?

- Não. Esse afastamento não impede a percepção dos vencimentos e demais vantagens permanentes, inerentes ao car go efetivo, ou, se for o caso, dos vencimentos do cargo em $\mathrm{co}^{-}$ missão ou função gratificada, vedada, tão-somente, a concessão de transporte, vantagens ou auxílios de qualquer espécie por parte de instituições públicas, sejam quais forem a origem e a natureza dos recursos que custeariam as respectivas despesas.

- Se um funcionário tiver que afastar-se para o exterior em missão oficial, em razão de bolsa-de-estudo, ou de desempe nho de outras atividades que digam respeito a seu aperfeiçoa- 
mento funcional, e estiver no regime de tempo integral e dedicação exclusiva, perderá a gratificação?

- Não. Continuará a percebê-la desde que a missão ou estudo no exterior decorra do desempenho do cargo, ou seja condição para seu melhor exercício em futuro imediato. Isso, entanto, não impede que, por outros motivos, cesse, em relação ao funcionário, o regime de tempo integral e dedicação exclusiva, ou seja reduzida a respectiva gratificação, de acordo com a legislação em vigor.

\section{- E quando o funcionário acumular cargos ?}

- Se o afastamento não for julgado de interesse da Administração, quanto a um dos cargos acumulados, o funcionário somente poderá ausentar-se do País com perda dos vencimentos e vantagens de um deles...

- E o período de afastamento?

- Será considerado, nesse outro cargo, como licença para trato de interesse particulares.

- Qual o órgão do DASP que cuidaria desse assunto ?

- Seria a Coordenação de Atividades de Aperfeiçoamento (CODAPER), considerada Órgão Central do Subsistema de Aperfeiçoamento do Pessoal Civil, hoje, de certo modo, voltada mais para o treinamento do pessoal com vistas a compatibilizá-lo com a implantação do novo Plano de Classificação de Cargos... Neste Sentido, cumpre verificar o que dispõe o Decreto n. 73.421 , de 4 de janeiro de 1974 (Diário Oficial) de 7 de janeiro de 1974). O DASP, quando solicitado, tem se limitado à verificação final de observância dos requisitos legais para a autorização do afastamento pelo Presidente da República.

- Como se procede com um funcionário ocupante de cargo em comissão ou de função gratificada, no caso de afastamento para o exterior?

Sên - Se não ocorrer a exoneração ou a dispensa durante a aumas:

rio a) na hipótese de missão oficial do Governo, o funcioná a continuará a perceber o vencimento do cargo em comissão ou a gratificação de função, qualquer que seja o período; 
b) na hipótese de bolsa-de-estudo sobre assunto diretamente vinculado às atribuições do cargo por ele ocupado, poderá o funcionário, a critério da Administração, continuar a perceber o vencimento do cargo em comissão ou a gratificação de função, desde que o afastamento não seja superior a cento e oitenta dias.

\section{- O pagamento é feito em dólares ?}

— Não! O pagamento dos vencimentos e demais vantagens nos casos de afastamentos para o exterior será feito em moeda nacional, em qualquer daquelas hipóteses.

- A que autoridade serão submetidas as propostas e os pedidos de afastamento para o exterior?

- Serão submetidas aos Ministérios de Estado ou aos dirigentes de Orgãos integrantes da Presidência da República, como - Conselho de Segurança Nacional, o Serviço Nacional de Informações, o DASP, a Consultoria-Geral da República etc.

- Quem propõe as viagens ao estrangeiro para execução de determinado trabalho?

- São os órgãos diretamente interessados. Antes, tais propostas eram feitas ao Presidente da República.

\section{- Dessas propostas e desses pedidos constará o quê ?}

- Deverão constar expressamente, nome e cargo do funcionário; natureza da missão ou da atividade de aperfeiçoamento: prazo de duração da permanência no exterior, incluído o período de trânsito, de acordo com o meio de transporte utilizado; indicação das vantagens a serem concedidas, acompanhadas dos respectivos quantitativos, discriminadas em cruzeiros; dotações orçamentárias ou quaisquer outras fontes de recursos à conta das quais correrão as despesas, indicando-se a existência de saldo; indicação circunstanciada do interesse da Administração, nos casos de bolsa-de-estudo e de desempenho de outras atividades que visem ao aperfeiçoamento funcional; documentação relativa à bolsa-de-estudo, ao convite ou outra forma de iniciativa do afastamento, com resumo em porutguês, quando escrita em língua estrangeira: indicação, se for o caso, do Diário Oficial que publicou a autorização do último afastamento do funcionário para o exterior. bem como a data da posterior reassunção do exercício. 
- A que ficará obrigado o funcionário que afastar-se para - exterior por motivo de bolsa-de-estudo ou desempenho de outras atividades com vistas a seu aperfeiçoamento funcional ?

das - Ficará obrigado a apresentar relatório circunstanciado das atividades exercidas.

- Há prazo para apresentação desse relatório ?

a Sim. Deverá ser ele apresentado dentro de sessenta dias cargo da data em que o funcionário reassumir o exercício do

- Há limite de tempo para os afastamentos para o exterior?

- Sim. Em qualquer hipótese, o afastamento do funcionário não poderá exceder de quatro anos. Salvo no caso de afastamento para trabalho junto a Organizações Internacionais com as quais coopere o Brasil. E somente após o decurso de igual lap. so de tempo, isto é, quatro anos, contado do término do período relativo à última missão ou estudo, poderá o funcionário novamente ausentar-se do País, para estudo ou missão oficial, observados, sempre, o interesse e a conveniência da Administração.

féri Lé necessário autorização para o funcionário em gozo de érias ou de licença afastar-se do País?

- Não. Poderá afastar-se do País independentemente de autorização, devendo, entanto comunicar seu endereço eventual na forma do que dispõem os artigos 87 e 96 da Lei n. 1.711 , de 28 de outubro de 1952. Ção Direta?
- Não. Estas normas, consubstanciadas no Decreto n. 61.775 , de 24 de novembro de 1967, são aplicáveis aos servidores tatutárarquias federais, estejam eles submetidos ao regime estatutário ou sujeitos à legislação trabalhista, assim como aos funCionários públicos federais em exercício em entidades da Administração Indireta, inclusive Fundações criadas pelo Poder Público.

- Quem autoriza o afastamento de servidor autárquico ?

tiver - $\mathrm{O}$ afastamento será autorizado pelo Ministro a quem es- 


\section{- Há algum funcionário excluído deste regime?}

- Sim. Os diplomatas. O pessoal abrangido pela Lei $n$. do do pessoal docente de nível superior, vinculado à Administração Federal. Os funcionários que forem servir em organizações internacionais com as quais o Brasil coopere, na forma do Decreto-lei n..$^{\circ} .538$, de $1 .^{\circ}$ de agosto de 1946 , como a ONU, a FAO, a UNESCO.

- No caso de o funcionário afastar-se para servir nessas organizações internacionais com as quais coopere o Brasil, quem autoriza 0 afastamento ?

- Bem, de acordo com o disposto no Decreto n. 61.775 , de 24 de novembro de 1967, esse tipo de afastamento será au. torizado pelo Ministro de Estado ou dirigente de Órgão integrante da Presidência da República. Acontece, porém, que, de conformidade com o que dipõe o Decreto $n .^{\circ} 67.494$, de 6 de novembro de 1970 , as viagens para missão ou estudo no estrangeiro, com ônus ou sem ônus para os cofres públicos, somente serão permitidas com prévia e expressa autorização do Presidente da República.

- Se um funcionário obtiver bolsa-de-estudo de instituição nacional ou estrangeira, para aperfeiçoar-se ou especializar fora do País, e se, depois de tanta despesa, voltar e deixar o Serviço Público para ir dedicar-se a seus interesses particulares? Nada lhe acontece ?

das as - Será ele obrigado a indenizar os cofres públicos por tono as despesas ! Despesas feitas com a viagem e manutenção no estrangeiro. Para evitar que isso aconteça, não poderá o servidor, durante cinco anos de seu regresso, requerer licença para 0 trato de interesses particulares ou exonerar-se do cargo, desvincular-se do Serviço Público.

\section{- Nem se aposentar?}

- Exatamente! Nem se aposentar, salvo se por motivo de doença, invalidez ou compulsoriamente!

\section{- Isso tem acento em lei ?}

- Sim. Está expresso no Decreto-lei n. 7.729 , de 12 de julho de 1945, que também determina que deve voltar ao Brasil. dentro de trinta dias, a contar da data em que receber a ordem, 0 
servidor em viagem de estudos que deixar de cumprir as normas constantes desse diploma legal, as instruções especiais ou do ato que autorizar sua viagem, bem como se não conseguir aproveitamento suficiente nos estudos...

\section{- E se, dentro desse prazo, não regressar ?}

- Findo o prazo de trinta dias, perderá direito ao vencimento ou salário e qualquer vantagem que the tenha sido assegurada.

- 0 órgão de pessoal deverá, então estar atento...

- Sim, bem como o chefe imediato do servidor, pois que - processo de indenização terá início pelo próprio servidor, com a comunicação ao chefe imediato do propósito de deixar o serviço público, ou ex officio, desde que verificado o afastamento definitivo, caso em que será da alçada do órgão de pessoal sob cuja jurisdição estiver o servidor. Para tanto, manterão os órgãos de pessoal um registro das despesas de viagem dos servidores enviados ao estrangeiro, em que se especifiquem o vencimento ou salário e cada uma das vantagens percebidas de acordo com a legislação própria.

\section{do País precisará de pedir autorização?}

- Não. O inativo é livre de ausentar-se do País sem necessidade de autorização, apenas exigida a autorização presidencial para a aceitação de representação de Estado estrangeiro, dentro do País ou fora dele ${ }^{5}$. Por igual, independe de autorização do Presidente da República o afastamento do País de servidores em gozo de férias ou licenças legalmente concedidas, ${ }^{6}$ bastando comunique ele a seu chefe o endereço eventual ou local onde poderá ser encontrado.

- Qual a legislação aplicável a afastamento para o exterior de ocupante de cargo de Médico do Quadro de Pessoal do Ministério das Relações Exteriores que deverá estagiar em Escola de Medicina?

- Entendeu já o DASP que esse afastamento deve processar-se na forma do Decreto n..$^{\circ} 61.775$ de 24 de novembro de 1967 ,

5. V., nesse sentido, parecer do Consultor Jurídico do DASP no Processo n.० 1.262/55. Dlário Oficlal de 26 de março de 1955, p. 5.459.

6. Formulaçăo $n \cdot 0^{\circ} 209$

R. Serv. públ., Brasília, 109 (1) Jan./mar. 1974 
alterado pelos de n.'s 63.012, de 18 de julho de 1968, e 67.494, de 6 de novembro de 1970, e não pelo Decreto-lei n. 7.729 , de 12 de junho de 1945, ou pela Lei n. 5.809 , de 10 de outubro de 1972. ${ }^{7}$

Vimos, então, o afastamento a serviço da União e em razão de bolsa-de-estudo ou desempenho de atividades com vistas a seu aperfeiçoamento, afastamento este com base no Decreto-lei n. 7.729 , de 12 de junho de 1945 , alterado pelo Decreto-lei $n .^{\circ}$ 9.688 , de 30 de agosto de 1946.

Vejamos, agora, o afastamento para servir em organizações internacionais com as quais o Brasil coopere, permitido pelo Decreto-lei $n .^{\circ} 9.538$, de $10^{\circ}$ de agosto de 1946 .

Diz expressamente o artigo $10^{\circ}$ desse diploma legal que ao servidor da União, mediante expressa autorização do Presidente da República, é permitido o afastamento do País, para o fim de executar trabalho que the confiar qualquer Organização Internacional com a qual coopere o Brasil.

\section{- Quais essas Organizações Internacionais ?}

- Organizações Internacionais com as quais coopere o Brasil săo, exemplificativamente, a Organização dos Estados Americanos (OEA), a Comissão Econômica para a América Latina (CEPAL), o Instituto Latino-Americano de Planejamento Econômico e Social (ILPES), o Centro Latino Americano de Demografia (CELADE), o Banco Internacional de Reconstrução e Desenvolvimento (BIRD), o Fundo Monetário Internacional (FMI), o Centro Internacional de Comércio (GATT), a Organização Internacional do Trabaiho (OIT), a Organização Mundial de Saúde (OMS), a Organização Internacional de Telecomunicações (UIT), a Organização das Nações Unidas para a Educação, Ciência e Cultura (UNESCO), o Instituto das Nações Unidas para Treinamento e Pesquisa (UNITAR), o Banco Internacional de Desenvolvimento (BID) etc.

mento ? Qual o critério de contagem do período desse afasta-

Conta-se o afastamento a partir do dia seguinte ao do desligamento do servidor da repartição ou serviço em que estiver lotado, até ao dia do retorno às suas atividades administrativas normais ou comuns. 7. Entendimento do Coordenador de Legislação de Pessoal exarado a 20 de março de 1973 no
Processo n.० 1.046/73. Não publicado.

R. Serv. públ., Brasília, 109 (1) Jan./mar. 1974 
se à repartição ?

- Sim, executado o trabalho que lhe cumpria, disporá o servidor de um prazo de 120 dias para apresentar-se à repartição ou serviço em que estava lotado, ao tempo de seu desligamento.

- Durante a execução do trabalho, continuará o servidor a perceber vencimento ou remuneração ?

- Não. Durante o tempo em que estiver afastado perderá o vencimento, remuneração ou salário, contando-se-lhe, entanto, para efeito de aposentadoria e disponibilidade, o tempo de serviço correspondente ao afastamento.

ração ?

- Como se habilita o servidor para prestar essa coope.

- Há os que são convidados nominalmente e os que se candidatam à realização do traballho. $\mathrm{Na}$ primeira hipótese, os convites são formulados através do Ministério das Relações Exteriores que os levará ao conhecimento do DASP para as providências necessárias. $O$ servidor convidadó nominalmente prescin. dirá de ser selecionado pelo DASP o que não acontece com os que se candidatam a prestar a colaboração. Em qualquer caso, porém, cumpre ao DASP propor a concessão do afastamento, a convite nominal ou mediante seleção, bom como fazer as devidas comunicações e preparar os expedientes complementares necessários.

zer?

- E ao Ministério das Relações Exteriores o que cabe fa-

- A esse Ministério incumbe cientificar o DASP dos con. vites nominais e das solicitações de pessoal que forem feitas por seu intermédio, bem como de término do trabalho confiado ao servidor público.

- Outra hipótese de afastamento é a para participar de competição desportiva internacional de amadores...

- Sim, e se fundamenta no Decreto-lei n. 3.199 , de 14 de abril de 1941, ainda em vigor. De modo que, para participar de competição desportiva internacional de amadores, dentro ou fora do País. poderá o Conselho Nacional de Desportos, mediante prévia autorização do Presidente da República, requisitar à autori- 
dade competente qualquer funcionário, inclusive servidor contratado, sem prejuízo das vantagens do cargo ou função. Se se tratar de empregado em serviço particular, poderá, igualmente, fazer-se a requisição, sem prejuízo do jogador, cumprindo, todavia, à Confederação interessada, indenizar o empregado do prejuízo correspondente ao salário por ele recebido. Reparar que dissemos o empregado e não o empregador, como está na lei, porque é só aquele que poderia ter prejuizo que correspondesse a salário por ele vencido e não o empregador, evidentemente.

Freqüentemente se processa afastamento de servidores para fins religiosos ou culturais. O Decreto $n .^{\circ} 61.998$, de 28 de dezembro de $1967^{8}$, dispõe sobre a dispensa de ponto de servido. res públicos federais, para comparecimento a congressos ou reuniōes similares, no País ou no exterior.

- Qual a autoridade federal legalmente competente para autorizar a dispensa de ponto ?

- Somente o Presidente da República poderá autorizar a dispensa de ponto para que funcionários públicos federais, seja da Administração Direta seja das Autarquias, possam comparecer a congressos, conferências ou outros conclaves, no País ou no exterior.

\section{- Qualquer tipo de conclave ?}

A dispensa de ponto poderá ser concedida quando se tratar de conclaves de natureza científica, artística, cultural ou equivalente, cuja finalidade seja de relevante interesse público.

\section{- Por quanto tempo será autorizado o afastamento ?}

- A autorização abrangerá o período estritamente necessário ao comparecimento do servidor ao conclave, nele incluídos os dias de viagem.

\section{— Há normas a serem observadas ?}

- Sim. As entidades patrocinadoras do conclave deverão formular o pedido de autorização com observância das seguintes normas : a) o pedido deverá ser dirigido ao Presidente da República, através do Ministério ou órgão público interessado, acom. panhado de ampla justificação; b) o pedido deverá ser formula-

8. Diário Oficlal de 29 de dezembro de 1967

R. Serv. públ., Brasília, 109 (1) Jan./mar. 1974 
do, no mínimo, 30 dias antes da data marcada para o início do conclave; c) com pronunciamento conclusivo do Ministério ou órgão público, o pedido será submetido à decisão presidencial; d) a decisão presidencial deverá ser transmitida à entidade solicitante.

- Que compete fazer ao servidor interessado?

- Os servidores que se beneficiarem com a dispensa de ponto deverão comprovar, perante o chefe da repartição, o comparecimento e a freqüência ao conclave mediante atestado fornecido pela autoridade patrocinadora.

\section{- Como procederá, então, o chefe ?}

- Recebido o atestado, o chefe da repartição o encaminhará imediatamente ao órgão central de pessoal, para os devidos registros.

Vale observar que, com fundamento e nos termos deste mesmo Decreto n. 61.998 , de 1967 , excepcionalmente poderão ser dispensados do ponto os funcionários que, comprovadamente, comparecerem a congressos de natureza religiosa, filantrópica ou cultural, ficando o assunto à discrição exclusiva do Presidente da República.

Por fim, temos o afastamento do ocupante de cargo de magistério superior, para estudo ou missão oficial no exterior.

- Quer dizer que os professores universitários têm disciplinamento próprio para afastamento?

- Sim, os regidos pelo Estatuto do Magistério Superior a que se refere a Lei n. $4.881-A$, de 6 de dezembro de $1965^{\circ}$, o que não importa dizer que o ocupante de cargo de magistério não passa afastar-se com fundamento em outro diploma legal.

\section{- Em que hipóteses poderá ocorrer o afastamento do ocu- Pante de cargo de magistério superior?}

ções, nacionais e estrangeiras; b) para comparecer a congresSos e reuniões relacionadas à sua atividade docente; c) para prestação de assistência técnica.

9. Diário Oficial de 10 dezembro de 1965. 


\section{- Quem autoriza esse afastamento ?}

- O afastamento dependerá de autorização do Reitor, nas Universidades, ou do Diretor, nos estabelecimentos isolados, após pronunciamento favorável da congregação ou colegiado equivalente da unidade.

- Mas, não foi dito que qualquer tipo de afastamento do País dependerá de autorização do Presidente da República.

- Sim, o preceito que acima citamos é reprodução de um dispositivo da referida Lei n. 4.881-A, de 1965 , que foi vetado pelo Presidente da República porém mantido pelo Congresso Nacional. Como o Presidente da República tem a prerrogativa constitucional de exercer a direção superior da administração federal, na qual se incluem as Universidades, é uma questão de disciplina a obediência ao Decreto $n \cdot 67.494$, de 6 de novembro de 1970 .

Vale notar que o afastamento do ocupante de cargo de magistério superior poderá ocorrer nos termos da referida Lei $n$. 4.881-A, de 1965, e da Lei n. 5.096, de 31 de agosto de $1966^{10}$. Este diploma legal diz que "os professores catedráticos e os integrantes do corpo docente e dos quadros administrativos das Universidades Federais só poderão ausentar-se do País, para estudo ou missão oficial no exterior, mediante autorização dos respectivos Reitores, depois de ouvidos os órgãos competentes".

O Decreto n. 59,676, de 6 de dezembro de $1966^{11}$, que regulamentou o Estatuto do Magistério Superior, incluiu como fundamento do afastamento de ocupante de cargo de magistério superior ambas as leis (art. 24), aduzindo que o afastamento dos ocupantes de cargos pertencentes às Universidades dependerá de autorização dos Reitores, e, nos demais casos, do Presidente da República, após o pronunciamento favorável da respectiva congregação ou colegiado equivalente.

\section{- E o afastamento do Reitor ?}

- Dependerá de parecer favorável do Conselho Universitário e de autorização do Ministro de Estado, de conformidade com o aludido Decreto n. . $^{59.676}$, de 1966, embora nos pareça deva ser obedecido o Decreto n. 67.494 , de 6 de novembro de 1970

10. Dlário Oficlal de $1.0^{\circ}$ de setembro de 1966

11. Diário Oficial de 7 de dezembro de 1966

R. Serv. públ., Brasília, 109 (1) jan./mar. 1974 


\section{- Quais as condições que justificam o afastamento ?}

dispõe o seu regulamento, os estatutos das 1965 , e com o que regimentos das suas unidades e dos estabelecimentos isolados especificarão as condições que justificam ou recomendam o afastamento, as normas a que deve obedecer bem como os prazos máximos para a sua duração.

\section{- 0 que cumpre fazer ao interessado?}

- Durante o período de duração do curso ou estágio bem como ao final de um ou outro, fica o interessado obrigado a remeter, ao órgão competente, relatórios das atividades executadas.

\section{- Há prazo para esse afastamento ?}

- Sim. A ausência não deverá ser superior a quatro anos, não sendo permitido outro afastamento, finda a missão ou o estudo, antes de decorrido igual prazo.

Demos, assim, breve notícia sobre essas seis hipóteses de afastamento do servidor público para o exterior, cuja legislação esparsa está a merecer uma consolidação para melhor atendimento dos interessados e da Administração federal. 
